\title{
The Transport and Deposition of Pyroclastic Material from the 1000 AD Caldera-Forming Eruption of Volcan Ceboruco, Nayarit, Mexico
}

\author{
B. L. Browne • J. E. Gardner
}

Received: 30 April 2007 / Accepted: 16 August 2007 / Published online: 9 October 2007

(C) Springer-Verlag 2007

Owing to an unfortunate oversight on the part of the publisher, the title was incomplete.

It currently reads, "The Transport and Deposition of Pyroclastic", but it should read, "The Transport and Deposition of Pyroclastic Material from the 1000 AD Caldera-Forming Eruption of Volcan Ceboruco, Nayarit, Mexico"

The online version of the original article can be found at http://dx.doi. org/10.1007/s00445-004-0390-6.

B. L. Browne $(\bowtie)$

University of Alaska Fairbanks Geophysical Institute,

Fairbanks, AK 99775, USA

e-mail: bbrowne@fullerton.edu

J. E. Gardner

Department of Geological Sciences,

University of Texas at Austin,

Austin, TX, USA 